\title{
Music Industry: Toward A New Business Model?
}

\author{
Alexis Koster, (E-mail: akoster@mail.sdsu.edu), San Diego State University
}

\begin{abstract}
The last ten years have seen many changes in the music industry, mainly caused by Internet music downloading, legal and illegal. The traditional business model of the recording music industry, based on the sales of CDs in retail stores, seems to be on its way out. No clear new model has emerged yet, but several trends are noticeable for the recording music industry. First, the decline of CD sales since the peak year of 2000 has accelerated, totaling 30\% in the USA. Second the recording music industry is going through a restructuring, marked by sell offs and mergers among the recording labels, by the disappearance of music retail stores, and by the foray of the majors in new directions, such as concerts. Finally, revenues from digital music sales are increasing, partially compensating for the decrease in $C D$ sales. Whereas the providers of content, namely the labels and the artists, can be seen as victims of music downloading, the providers of the technology have benefited. The sales of its iPod/iTunes systems have provided Apple's more revenues than the sales of its computers. Other manufacturers are also entering this market. Meanwhile, academics and policy makers have been studying new types of copyright licenses. One idea is to impose a global license, paid by Internet service providers, and repaid to them by Internet users. Many technological and legal questions must be resolved for such a scheme to become viable.
\end{abstract}

\section{THE CONTINUOUS DECLINE OF RECORDED MUSIC SALES}

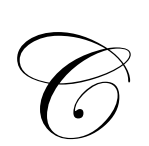

D dollar sales in the USA declined 12.9\% in 2006 from the previous year [1]. Since the peek year of 2000, CD sales have now dropped 30.6\% (even more if adjusting for inflation). The CD sales worldwide do not fare better. For example, France has seen a decline of $12.4 \%$ in 2006 [2], and a decline of $40 \%$ in four years. Since the US sales started declining between 2000 and 2001, the decline rate has also been increasing with the exception of 2003-2004, which saw a small increase of $1.9 \%$.

The music industry has been blaming music piracy, mainly illegal Internet downloading, for the decline of $\mathrm{CD}$ sales. Some researchers, for example Oberholzer-Gee and Strumpf, disagree with this view, proposing reasons connected the industry practices as well as to the economy [3]. Other researchers have sided with the music industry $[5,6]$. The Supreme Court was not convinced by the arguments developed by Oberholzer-Gee and Strumpf. They had filed a brief in favor of the file-sharing software developer Grokster in its legal fight against the recording music industry [4], but the Supreme Court found in favor of the music industry in 2005.

The decline of CD sales has accelerated in spite of a string of legal victories for the music industry against, among others, mp3.com, Napster, and Grokster, companies that promoted illegal music downloading. The legal actions against persons involved in illegal downloading seem to have had some effect in 2004, year which saw a slight increase in CD sales, but this effect did not last. Similarly the enactment of laws by the US Congress to prevent copyright infringement on the Internet seems to be ineffective. Maybe, without those legal and political actions, CD sales would have declined even more. 


\section{THE ON-GOING MUSIC INDUSTRY RESTRUCTURING}

To face the loss of revenues, the recording music industry has been looking for the bottom line. Two majors, Sony and BMG have merged. There are been efforts for EMI to merge with one of the remaining three majors, but without success so far. EMI has undergone its own internal restructuring by merging its two main record labels in the USA in January 2007. Warner Music was sold by its parent company in 2004.

The most visible change is the industry is the downsizing or disappearance of retail music stores. A large chain of music stores, the Wherehouse, filed for bankruptcy in 2003 and has gone out of business. Its buyer closed many of its stores, keeping a few ones open. Another chain of music stores, Tower Records, filed for bankruptcy in 2004 and was bought in 2006 for liquidation. Most independent music stores had already disappeared in the USA, but they still had survived in other countries. They are now disappearing in those countries. In France, for example, they numbered 500 in 2004; 200 are left in 2007.

CDs are sold more and more in large department stores such as WalMart and BestBuy. Rather than offering the large choice of music that music retail stores used to offer, they typically only sell the most popular CDs. This trend is likely to accelerate the decline of CD sales.

Traditionally, recorded music and concerts were two separate activities. The labels got their revenues from the sale of recorded music, mostly CDs. They were not involved in concerts. Surprisingly, recording artists who are successful, but not at the top, got little revenues from the sale of their CDs [7]. Their revenues came mostly from concerts. The labels saw the concerts as a way to advertise the CDs of their recording artists, many recording artists saws the sales of their CDs as advertisement for their concerts. Things are now changing. Labels are looking for new sources of revenues and are getting into the concert business. For example, the famous Paris concert hall Olympia was bought by Universal a few years ago and Sony-BMG bought another Paris concert hall in 2007 [8]. Similarly record producers are getting involved in the production of concerts.

\section{DIGITAL MUSIC SALES AND MUSIC DOWNLOADING}

Digital music, as defined by the Recording Industry Association of America (RIAA), includes mostly music downloaded over the Internet for a fee, music downloaded from subscription sites, and music downloaded to cellular phones and other mobile devices. The RIAA [1] has started keeping records of all those categories of digital music in 2005. The revenues in 2006 were as follows, in millions of dollars:

- $\quad$ downloads for a fee--

- $\quad$ subscription downloads--

- mobile--
856 , an increase of $72 \%$ 206 , an increase of $38 \%$ 774 , an increase of $84 \%$

Looking at the total revenues (CDs and digital music), the picture is not as grim for the recording music industry as indicated above. The drop in revenues from 2005 to 2006 is $6.2 \%$ instead of $12.9 \%$. The ratio of revenues from these 3 categories of digital music to $\mathrm{CD}$ sales is $20 \%$. The unanswered question for the music industry is: will the digital music sales continue their strong growth and compensate for further declines of CD sales? Note also that the number of units (songs or albums) legally downloaded (approaching the billion in 2006) still pales in comparison with the number of illegal downloads.

Legitimate music downloading keeps changing. Initial music sites provided very restricted catalogs of music (often limited to one or two labels). There were also strong limitations on what could be done with the downloaded music: number of copies, time limits, where to copy. Although Apple iTunes still works under this model for the number of copies permitted and the devices where copies are permitted, Apple has been able to negotiate a very large music catalog from the 4 labels for its music site. One large factor of the Apple success is the hardware device where music is normally stored and played back, the iPod. The revenues from the sales of iPod continue to grow very strongly ( $24 \%$ increase in one year in number of iPods). About two billion songs have now been downloaded from the iTunes site, at 99c per song [9]. 
Apple had gotten permission from the four majors to store their songs on its website for downloading by its customer under promise of enforcing copyright protection by technological means, the so-called Digital Rights Management or DRM. There is now a very strong push to do away with DRM because they make the use of downloaded or recorded music very cumbersome for the consumer. Apple CEO, Steve Jobs, has himself called for an end to DRM [9], probably due to new competition.

A new online music provider, eMusic, offers songs for download at 0.23 Euro (about 30 cents). With more than 250,000 subscribers, it is already the second digital music provider after Apple, having signed agreements with several independent labels [10]. In opposition to Apple iPod/iTunes, which uses a proprietary music format, eMusic uses Mp3, which can be played back on most computers and devices.

This push toward free (or at least "freer" music) is now coming from many directions, even from some of the majors. EMI will offer free streaming music on a Chinese Yahoo website. Warner Music will provide its video and music clips for free to a website called Dailymotion. An interesting aspect of this deal is that Warner Music will share advertisement revenues with Dailymotion. This could be a forerunner for dealing with the complex problem of copyright on the Internet.

The traditional license fees owed to the copyright holders by the consumer are obviously not collectable when music is downloaded illegally. Some researchers, particularly in France, have proposed that free music downloading over the Internet be made legal. A "global license" would be used to compensate the copyright holders: it would be paid by the Internet Service providers (ISP) based on the amount of music file traffic. They would then charge their customers a very low fee. The main problem with this scheme is that the technology is not available to identify the music downloaded, hence the copyright holders. This newly elected French president had previously indicated his opposition to free music downloading and this global license.

\section{CONCLUSION}

Attributed to music piracy over the Internet, the decline in CD sales, which started in 2001, has recently accelerated, both in the USA and abroad. The revenues from digital music, in particular paid music downloads over the Internet, have sharply increased, but not enough to compensate for the losses of CD sales. The music industry is restructuring to face this loss of revenues: internal reorganizations and mergers of labels, disappearance of music retail stores, and involvement of labels in the concert business.

The Internet music business, where Apple is striving with its iPod/iTunes system, is also facing many pressures and already changing toward less limitation and freer access to music. The majors themselves are getting involved in those changes.

\section{REFERENCES}

1. de la Merced, Michael. Apple's Chief Calls for End to Music Copy Protection. The New York Times, February 7, 2007

2. Demarthon, Jacques. Record Producers Become Concert Producers. Le Monde, May 9, 2007 (in French)

1. $\quad$ Hache, Valery. Midem 2007: a dark year for the CD." Le Monde, March 10, 2007 (in French)

2. Oberholzer-Gee, Felix and Koleman Strumpf. Brief Amici Curiae to the Supreme Court, 2005.

3. Oberholzer-Gee, Felix and Koleman Strumpf. The Effect of File Sharing on Record Sales-An Empirical Analysis, working paper, Harvard Business School, March 2004.

3. Peitz, Martin and Patrick Waelbroeck. The Effect of Internet Piracy on Music Sales: Cross-Section Evidence, Review of Economic Research on Copyright Issues, 2004, 1(2).

4. Rather, Dan. CBS Broadcast 60 minutes, July 17, 2001.

5. www.ifpi.com. March 21, 200

4. $\quad$ www.ria.com. 2006 Year-End Shipment Statistics, 2007

6. Zentner, Alejandro. Measuring the Effect of Internet Piracy on Music Sales, working paper, University of Chicago, 2003. 
Journal of Business \& Economics Research - November 2007

Volume 5, Number 11

NOTES 